\title{
Cuerpos humanos y cuerpos utópicos: el deseo mimético en La Desdichada,
}

de Carlos Fuentes

Human bodies and utopian bodies: Mimetic Desire in La Desdichada [The miserable] by Carlos Fuentes

Universidad de Concepción, Chile (iD) https://orcid.org/-0001-0000 4530-6305

Resumen: Con base en las propuestas teóricas de Jean Baudrillard, Michel Foucault y René Girard, se analiza el funcionamiento del deseo mimético y los cuerpos utópicos en La Desdichada (1989), relato de Carlos Fuentes que forma parte del volumen Constancia y otras novelas para vírgenes. La relación afectiva que se desarrolla entre dos sujetos (los personajes Bernardo y Toño) y un objeto (un maniquí que adquiere su propia personalidad), se examina mediante distintas variantes de un deseo sexual triangular. Finalmente, se da cuenta del proceso por medio del cual se da la humanización e involución del objeto.

Palabras clave: literatura latinoamericana; literatura contemporánea; novela; análisis literario

Abstract: On the basis of the theoretical proposals of Jean Baudrillard, Michel Foucault and René Girard, the functioning of mimetic desire and utopian bodies in La Desdichada [The miserable] is analyzed. This short story by Carlos Fuentes is comprised in Constancia y otras novelas para vírgenes [Constancia and other stories for Virgins]. The affective relationship devolved between two individuals (the characters Bernardo and Toño) and an object (a mannequin that acquires its own personality) is examined by means of several variations of triangular sexual desire. Finally, there is an account of the process by means of which the humanization and involution of the object takes place.

Keywords: Latin American literatura; contemporary literatura; novels; literary analysis 


\section{INTRODUCCIÓN}

En La Desdichada — segundo relato del libro Constancia y otras novelas para vírgenes (1990)—, Carlos Fuentes nos acerca a un texto que podríamos catalogar de seductor. Esto, debido al lenguaje, el misterio narrativo (en ocasiones francamente dramático), y el tema que conduce la obra: las relaciones afectivas entre personajes humanos y no-humanos, y los conflictos que producen estas pasiones del cuerpo y del alma. El universo ficcional de La Desdichada dialoga con las otras novelas del libro. El autor imagina un espacio donde las historias se interrelacionan, bien por medio de los sueños, bien por la coincidencia de algún personaje, lugar o hecho. Más allá de estas particularidades, la crítica reconoce en Constancia y otras novelas para vírgenes la consolidación de una narrativa enmarcada en un "proyecto nacional", cuyo cénit literario lo constituye Pedro Páramo, de Juan Rulfo (Hernández, 1991: 231). Aunque en la escritura de Fuentes se percibe la influencia de Rulfo, el autor de Aura ubica sus tramas en un espacio totalmente distinto: la ciudad, con un predominio de lugares cerrados e intimistas, como casas, habitaciones, áticos. Esto favorece la aparición de sitios heterotópicos, ideales para desencadenar los conflictos que se desarrollan en los relatos de este libro.

Las pasiones y exaltaciones del amor, particularmente el erotismo, constituyen uno de los rasgos distintivos del estilo de Fuentes. Herrera afirma que en el escritor mexicano "lo erótico y lo literario comparten una misma raíz: el deseo" (1991/1992: 108); y La Desdichada es justamente uno de los textos donde más nítidamente se evidencia este punto: el anhelo sexual y afectivo, así como las aspiraciones literarias de los personajes, conducen las acciones de los amigos Toño y Bernardo, y determinan su disposición hacia la Desdichada, el maniquí que de a poco gana protagonismo en sus vidas. En este sentido, Mesa Gancedo asegura que en el discurso de Fuentes los maniquíes resultan "ambiguos objetos de deseo por parte de personajes masculinos" (2002: 100). Esa atracción, que en el universo ficcional se describe como mutua, transgrede los cánones antropocéntricos de la sexualidad. Con ello se entremezclan las fronteras entre objetos y sujetos, cuerpos artificiales y cuerpos biológicos y, en última instancia, entre lo humano y lo no-humano.

La dimensión de lo deseante ha sido poco abordada por la crítica sobre Carlos Fuentes. El presente artículo analiza esta temática desde la propuesta de René Girard. El objetivo principal es examinar cómo el deseo mimético influye en la humanización e involución de un objeto (el maniquí-mujer denominado la Desdichada) mediante la seducción de los sujetos (Toño y Bernardo). Se verifica cómo se impone el modelo de imitación entre los personajes mediante la configuración de un triángulo. En el texto se imita el deseo ya experimentado por un otro - lo que Girard llama 'deseos idénticos'-, situación que forzosamente desemboca en la conversión de los amigos en rivales/obstáculos. Este fenómeno, que se da en los espacios heterotópicos de la narración, produce lo que conocemos como mediación interna. ${ }^{1}$

Con base en la noción de 'cuerpo utópico', descrita por Michel Foucault, se rastrea el tránsito del maniquí hacia la humanización y se detectan los elementos que lo impulsan. En dicho proceso figuran dos reinos: el de los objetos y el de las personas, entre los cuales ocurre lo que Deleuze y Guattari denominan 'devenir'. Se plantean interrogantes sobre dicha transformación, así como sobre la raíz deseante en lo literario y lo erótico. En este análisis se considera a la Desdichada como objeto o sujeto, persona o no-persona, humana o no-humana. Finalmente, se identifica qué sucede cuando el deseo sexual deviene de

1 "Hablaremos de mediación externa cuando la distancia es suficiente como para que las dos esferas de posibles, de las cuales el mediador y el sujeto ocupan los centros, no puedan entrar en contacto. Hablaremos de mediación interna cuando esa misma distancia es lo bastante reducida como para que las dos esferas se penetren más o menos profundamente" (Girard, 1963: 13) 
sujeto-objeto a sujeto-sujeto, y cuando el objeto de deseo se humaniza y adquiere un cuerpo utópico anhelado.

\section{LA PERSONIFICACIÓN DEL OBJETO}

La Desdichada, personaje que da nombre a la novela, es un maniquí que asemeja la forma de una bella mujer:

Su escultor le dio un rostro de facciones clásicas, nariz recta y ojos separados [...] la boca de la muñeca, tiesa, chiquitita y pintada en forma de alamar, podría ser la de cualquier mona de aparador [...] También tiene un cuello largo, ideal para esos vestidos antiguos abotonados hasta la oreja [...] [N]o es perfecta: le falta un dedo y no sé si se lo mocharon adrede o si fue un accidente (78-79). ${ }^{2}$

Desde la óptica de Jean Baudrillard, un maniquí de madera puede considerarse un ser, pues $\mathrm{su}$ forma circunscribe al objeto - un fragmento de naturaleza de origen vegetal-, como en el cuerpo humano, y es fundamentalmente antropomórfico (1968: 28). Toño y Bernardo, las víctimas de la peculiar seducción de la Desdichada, no ven en ella una entidad inanimada, sino que vislumbran a una persona: "sólo una figura de mujer tenía una cabellera real, no pintada sobre madera, sino una peluca negra, un tanto apelmazada pero alta y antigua, con rizos" (65).

Según el valor que los personajes le confieren, el maniquí puede concebirse como un objeto con alma $^{3}$ que provoca placer y roza constantemente las fronteras entre lo vivo y lo muerto, lo inanimado y lo animado, y que a su vez deviene de manera paulatina en humano. A esta conclusión

2 Todas las citas pertenecientes a La Desdichada corresponden a Fuentes, 1990, por lo cual sólo se anota el número de página.

3 Para Baudrillard, los objetos ejercen una función primordial: la de "vaso de lo imaginario" (1968: 27), y tienen la capacidad de "personificar las relaciones humanas, poblar el espacio que comparten y poseer un alma" (1968: 14). se arriba por varios caminos. En primer lugar, el análisis intertextual revela una verdad oculta en la narración: antes de los sucesos de $L a$ Desdichada, la historia de la muñeca aparece en los sueños de la protagonista que da nombre a la primera novela del libro Constancia y otras novelas para vírgenes. La mujer sueña que es un maniquí, dos estudiantes la roban de una vitrina, la llevan a vivir a su departamento, se enamoran de ella y terminan destruyéndola. ${ }^{4}$ En cierto modo, La Desdichada constituye la trama del sueño de Constancia, y la muñeca, una prolongación del estado onírico de la mujer. Ahí radica el primer rasgo de personificación del objeto inanimado, de atisbo de vida en el maniquí. Tal conexión intertextual ${ }^{5}$ con un personaje humano constituye un vínculo en el que, además, radica la corporeidad (utópica) del ser. Gracias a este recurso narrativo podemos deducir que, por un lado, la Desdichada constituye el cuerpo utópico soñado por Constancia, y por otro, la mujer resulta el soporte imaginario desde donde se desprende lo humano de la muñeca. Entre lo animado y lo inanimado se establece una relación especular de mutua resignificación. Para Michel Foucault, un 'cuerpo utópico' puede entenderse como un "cuerpo sin cuerpo", que no corresponde necesariamente a un organismo vivo, pero del cual "salen e irradian todos los lugares posibles,

4 En Constancia, Fuentes narra: "Ella soñó que: Era un maniquí en un aparador. Dos muchachos traviesos, quizá dos jóvenes estudiantes, la roban de la vitrina y la llevan a vivir a su estudio. Dan cenas en su honor. Nadie sabe si ella, Constancia, está viva o muerta, ni los burlados ni los burladores. Los estudiantes se enamoran de ella, se disputan por ella, pero al cabo la destruyen: o quizás (el sueño es ambiguo) la abandonan para salvar su amistad masculina. Pero ella triunfa, madre Ana, madre mía (dice por primera vez este nombre delirando) y se impone a estos pobres amores impuros, madre mía, recorridos por la vanidad sexual masculina, que es la peor de todas porque todo se lo perdona a sí misma pero no le perdona nada a una mujer, nada, madre, pero ella se impone, ella reaparece y los mira a ellos como si ellos fueran los muñecos de palo, ella está viva; ella está en su lugar: Bendita eres entre todas las mujeres... ime oyes, madre?" (1990: 25).

5 Genette entiende por intertextualidad "una relación de copresencia entre dos o más textos, es decir [...] la presencia efectiva de un texto en otro" (1989: 10). En este caso, La Desdichada y Constancia están en copresencia, influyéndose y resignificándose mutuamente. 
reales o utópicos" (2010: 16). La Desdichada constituye así una emanación de Constancia, y la mujer, una emanación de la Desdichada; lo cual implica que el cuerpo-humano del maniquí se encuentra en otro lugar (real o utópico), más precisamente, en otro texto: Constancia.

En segundo lugar, el devenir humano de la muñeca puede rastrearse en las marcas corporales que el personaje adquiere paulatinamente, $o$ bien los estudiantes le proyectan desde su fascinación. En un primer momento, la muñeca es descrita con un cuerpo de palo barnizado, que viste un "elegante vestido de novia y un velo", como si fuese una máscara que le cubriera el rostro pálido y resaltado con pintura. Estos afeites, según Foucault, "depositan sobre el cuerpo todo un lenguaje enigmático, cifrado, secreto, sagrado que llama sobre ese mismo cuerpo la vivacidad del deseo" (2010: 13). En esos detalles aflora la naturaleza seductora que Toño y Bernardo creen descubrir en el objeto.

El deseo se despierta en los estudiantes cuando se topan a la muñeca adornada con un "elegante vestido de novia" y, prendados, deciden robarla. Según Foucault, a los ojos de Toño y Bernardo este primer atavío determina la 'personalidad' del maniquí. Cuando los jóvenes regresan a la tienda de la calle Tacuba para hurtarla, encuentran que la han desvestido y colocado entre los demás muñecos. En medio de los objetos uniformes les resulta irreconocible: "al igual que los cuerpos en la vida, un maniquí sin ropa deja de tener personalidad [es sólo] un pedazo de madera" (65), afirma Toño. Pero con ropa, en particular el vestido de novia, adquiere una 'personalidad deseable', al punto de que los muchachos necesitan hurtarla y llevarla a casa a 'vivir' con ellos. Como buenos coleccionistas, identifican a la muñeca por su mirada triste y porque en sus mentes gravita una figura femenina real, con la esbeltez y seducción de otra época.

Cuando la supuesta novia-virgen abandona la castidad — resguardada por el aparador-, parece amoldarse al abrazo que le ofrece Toño al transportarla, abrazo que se transforma en placer al arribar a la pequeña habitación a la que la trasladan, semejante a un ático de la bohemia parisiense. Al llegar, el joven la cubre con una bata china estampada de dragones paralíticos, perteneciente a un viejo tío "pederasta regiomontano"; finalmente, la viste con ropas robadas de las lavanderas del patio y "de las fichadoras del prostíbulo Waikikí". Es en este momento cuando el maniquí "retorna" a la vida y aprueba la decisión de los muchachos, no sin antes mostrar el recato de tiempos pasados: "entrecerró los ojos y bajó los párpados una fracción de centímetro" (67), asegura Toño.

La Desdichada cobra vida a medida que se apropia del vestuario de otras personas, lo que en el juego ficcional implica asimilar sus 'personalidades'; en este caso, las de un pederasta y unas prostitutas. Con este gesto comienza la sexualización del maniquí y se acelera el tránsito hacia su humanización. Dicho proceso posee dos momentos fundamentales. El primero y más inmediato lo constituye el otorgarle un nombre propio al objeto.

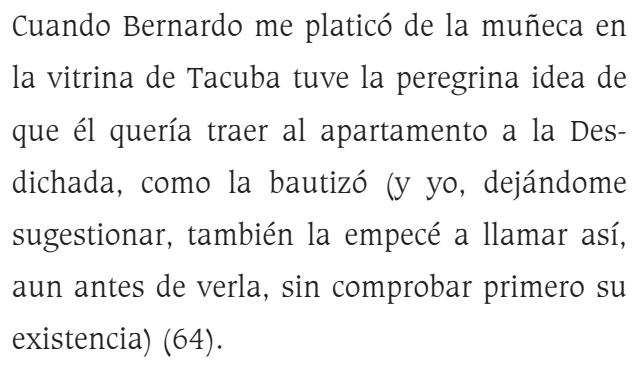

Con esta decisión, los amigos particularizan el objeto, trazan una línea divisoria entre la Desdichada y el resto de los maniquíes del mundo, le confieren identidad propia, una personalidad que resulta potenciada, realzada y resignificada mediante el vestido de novia con velo. Como ya se dijo, este afeite conduce al deseo por un cuerpo que desde el momento en que posee un nombre propio deja de ser "un pedazo de madera". 
El otro elemento clave que impulsa el tránsito hacia la humanización de la muñeca lo constituye el cariño que le proporcionan Toño y Bernardo. Al igual que con Pinocho, protagonista de la obra homónima de Carlo Collodi — quien revive por el amor de padre que le profesa el carpintero Geppetto-, el afecto desempeña la labor de catalizador en la simbiosis entre los personajes humanos y no-humanos. Tal coincidencia literaria - que ya viene a conformar un mito- confirma la tesis de Baudrillard de que la madera "puede convertirse en un ser vivo" (1968: 99), con sentimientos y delirios, tanto por su origen orgánico como por las cualidades que los coleccionistas le atribuyen. En la colección, advierte el autor, "el objeto cobra por completo el sentido del objeto amado" (Baudrillard, 1968: 99); en esa encrucijada el maniquí comienza a erigirse como objeto de deseo, lo que responde a un proceso de erotización que acelera su tránsito hacia lo humano.

\section{DESDICHA, MÍMESIS y DESEO}

En la época clásica, Aristóteles halló el vínculo entre mímesis (imitación) y deseo. En su Poética, el filósofo asegura que "la imitación es natural para el hombre", quien es "una de las criaturas más imitadoras del mundo" y cuyo modo de instruirse desde el comienzo "es por imitación” (1448b: 5-10). Acto seguido, enuncia que "aprender algo es el mayor de los placeres" (1448b: 10-15) para el hombre, y cita el ejemplo de la observación artística: "la razón del deleite que produce observar un cuadro es que al mismo tiempo se aprende" (1448b: 15-20). De este modo, el filósofo relaciona el deseo con la mímesis: ésta, al implicar un conocimiento, resulta placentera, y el placer es un deseo consustancial al ser humano, una motivación para encaminar sus acciones. Esa búsqueda del goce, según Aristóteles, motiva la aparición de las artes.
El debate sobre el vínculo entre mímesis y arte ha trascendido el campo de la imitación como búsqueda del placer y se ha instalado en el terreno de la teckné (operaciones y procedimientos que aluden a los modos de expresión de la experiencia). Paul Ricoeur entiende la actividad mimética no como "calco de la realidad preexistente ni redoblamiento degradado de la esencia", sino como "imitación creadora" (Paul Ricoeur en García, 2018: 43). Bajo esta línea puede interpretarse la actitud de Bernardo al traducir el poema "El desdichado", de Gérard de Nerval. Además de imitar las palabras del poeta — al trasladarlas al castellano-, parece 'imitar creadoramente' el pretexto lírico - la desventura de amor por la viudez-al darle su propia variación personal: el conflictivo vínculo con la Desdichada.

Bernardo centra su mente y energía en la composición del escritor francés: "El poema de Nerval es, literalmente, el aire de una estatua. No el que la rodea, sino la estatua misma hecha del puro aire de la voz que recita el poema” (65), afirma. Su apasionamiento encuentra en la Desdichada un objeto de adoración, pero pronto este sentimiento entra en conflicto con los anhelos de Toño, lo que enardece aún más su obsesión. Como asegura René Girard, la motivación del héroe hacia el objeto se agudiza en la competencia, en la pugna con un "tercero [que] está siempre presente en el nacimiento del deseo" (1963: 20). Esta situación determina los eventos posteriores al robo del maniquí, dando paso a la conformación de un triángulo de deseo mimético, en el cual la Desdichada constituye el objeto de deseo; Bernardo, el sujeto deseante; y Toño, el mediador u obstáculo para la consecución del deseo (Esquema 1). La trama subsiguiente de la novela versa sobre la evolución y resolución de este conflicto. 


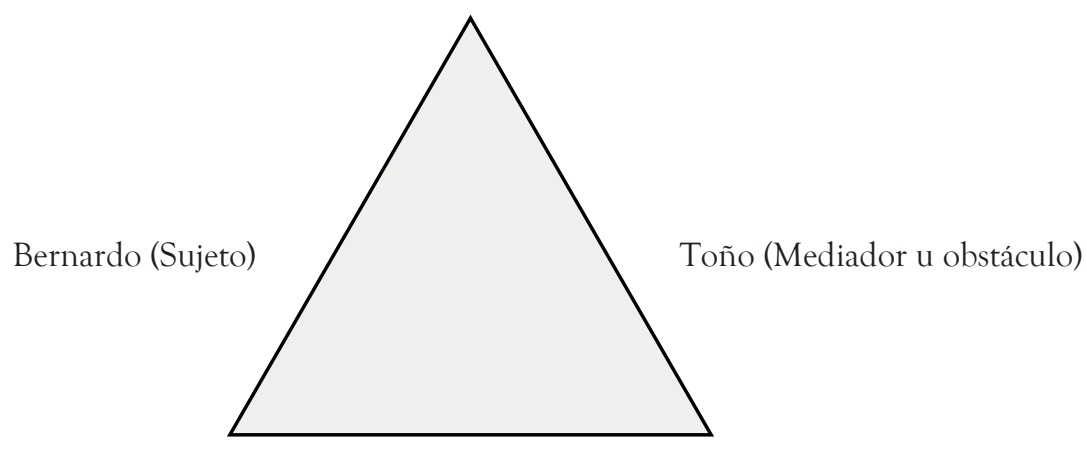

Fuente: Elaboración propia.

El análisis de La Desdichada, desde la teoría de René Girard, permite identificar cómo entre los personajes se impone un modelo de imitación ${ }^{6}(\mathrm{el}$ viudo del poema de Nerval), cuyo resultado lo constituye el maniquí devenido humano. Aunque esta transformación pueda ser ficcional, el deseo que la motiva resulta tangible y real, situación recurrente para los jóvenes. Bernardo y Toño suelen acudir a lecturas literarias para hallar modelos de imitación, usualmente asociados al sexo. Así sucede cuando Toño propone tener relaciones sexuales con dos prostitutas, pero imaginándolas como heroínas de la ficción (Marguerite Gautier y Delphine de Nucingen); ${ }^{7}$ o cuando al trasladarse a la capital para estudiar Leyes, los jóvenes pretenden emular a los personajes de Balzac y Octave Feuillet, para así encontrar "una amante madura, rica, casada, que los introduzca a los círculos de poder y fortuna" (69).

Como Don Quijote - quien se vuelve incapaz de elegir los objetos de su deseo, y en la fascinación, Amadís de Gaula escoge por él (Girard, 1963)—, Bernardo deja al poema de Nerval la construcción del objeto de su anhelo. El joven

6 Girard entiende por 'modelo de imitación' al personaje ficcional o real que es asumido por los sujetos en su actividad mimética. Está definido por una mediación externa y por otra interna (1963: 13).

7 Marguerite Gautier constituye la protagonista de la novela La dama de las Camelias. Delphine de Nucingen es un personaje recurrente en La comedia humana, de Honoré de Balzac. se convierte así en un "Tenebroso", un "Sin Consuelo", cuya "única estrella [la mujer amada] ha muerto" (Nerval, 1995: s/n). Las imágenes del soneto se apoderan de su mente. Pasa las noches y madrugadas traduciendo los doce versos del texto, lo cual confirma su estado obsesivo. La pasión que siente hacia el maniquí -que al portar un blanco vestido de novia adquiere la condición de ser amado y remite a la Santa de Nerval ${ }^{8}$ parece inducida por el estado de fascinación en el que lo sumerge el poema. La lectura insufla en Toño y Bernardo deseos que espontáneamente no experimentarían.

Como se mencionó, el modelo a imitar en esta situación deseante apunta a las imágenes del viudo desolado, al suplicio del amor perdido e irrecuperable. Lo que Bernardo no advierte es que Toño - su amigo y lector de las traduccionestambién actúa miméticamente y desarrolla la misma pasión hacia la Desdichada. Aquí se completa la tensión del triángulo del deseo mimético, pues se incorpora la perspectiva de Toño en el juego de fuerzas: ahora es él quien se percibe como el sujeto deseante y ve a Bernardo como el obstáculo o mediador que lo separa de la Desdichada, objeto que anhela (Esquema 2).

8 En la última estrofa del poema, la de mayor énfasis en los sonetos, leemos: "He, doble vencedor, traspuesto el Aqueronte: / Modulando unas veces en la lira de Orfeo / suspiros de la Santa y, otras, gritos del Hada" (Nerval, 1995: s/n). 


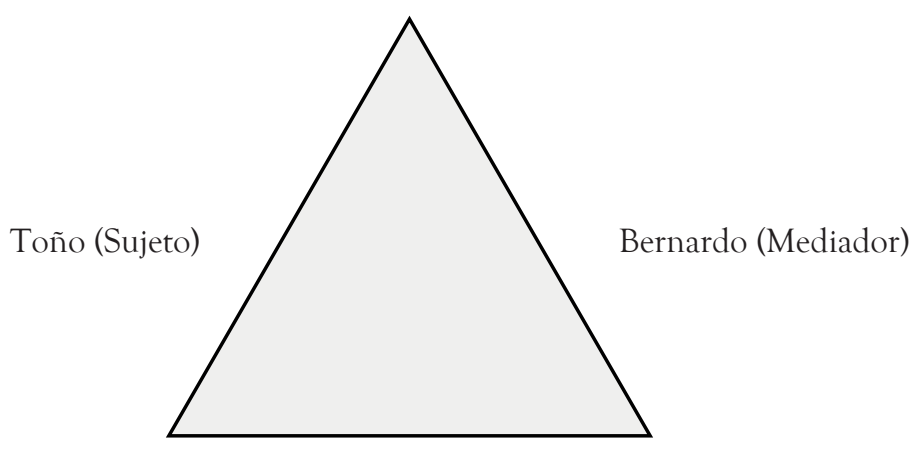

Fuente: Elaboración propia.

La variación ocurre en el modelo de imitación: si para Bernardo constituye el sujeto lírico del poema, para Toño es la obsesión desarrollada por Bernardo. Se consuma así lo que Girard considera un "deseo copiado de otro deseo", situación que conlleva, como consecuencia ineluctable, "la envidia, los celos y el odio impotente” (1963: 34). Lo anterior se percibe en el tono que usa Bernardo luego de que la Desdichada, con una "mirada sutil y estremecedora", elige a su amigo: "Ella está sentada a la mesa, envuelta en la bata china del tío marica. No mueve los ojos, claro, pero tiene la mirada fija, fija en Toño" (72). Este es el punto de no retorno de la situación. Al aflorar el anhelo colectivo, que vuelve bidireccional el triángulo del deseo (ambos jóvenes anhelan y se perciben mutuamente como obstáculos), la narración de Carlos Fuentes serpentea en un contrapunteo que provoca el dinamismo del relato, en una atmósfera que se torna romántica, violenta y triste a la vez.

El fundamento de la obra radica en esta tensión triangular. Si faltara alguno de los protagonistas no se produciría el dramatismo que espera el lector. El deseo por un tercero enriquece el diálogo, la reflexión, y confirma el enfrentamiento entre el sujeto y el mediador. Poner a los dos personajes frente a frente ante un mismo deseo los coloca en una encrucijada entre la amistad y el amor hacia un ser inanimado. De acuerdo con René Girard, "para que un vanidoso desee un objeto basta el convencerlo de que ese objeto es deseado ya por un tercero al que se asigna cierto prestigio. El mediador es aquí un rival" (1963: 10). Algunas escenas de la novela muestran cómo durante la convivencia los personajes entran en pugna por el objeto de deseo, lo que transforma el ambiente y su personalidad:

Volteo y por un instante no encuentro a la Desdichada: no la veo donde la dejé, donde debería estar, donde yo dispuse que se sentara frente a la mesa. Grito sin querer: «iAdónde te la llevaste?» Toño aparece solo apartando las cuentas de la cortina del baño. Tiene un arañazo en la cara. — Nada. Me corté. Ella sale ahora mismo (72).

La atracción real o supuesta del mediador (Toño) hacia el mismo objeto (la Desdichada) provoca la exaltación del deseo en el sujeto (Bernardo): ante sus ojos, la muñeca se vuelve infinitamente más apetecible, situación que aumenta el conflicto a causa de los celos del personaje. En el otro sentido del triángulo ocurre un fenómeno semejante: Toño, al ver multiplicadas las ansias de su modelo a imitar, lo emula. Se concreta así el engranaje de una máquina deseante que desestabiliza la atmósfera y produce tensión psicológica. Toño padece al rasurarse, mientras la Desdichada lo 
observa desde el inodoro con las piernas cruzadas: "Sentada allí, como quien no quiere la cosa, la rodilla protegiendo la rodilla. iBien coqueta! El excusado era sólo el lugar más cómodo para sentarla a ver cómo me rasuraba. Me puso nervioso, es todo" (73).

El juego de tensiones gira en torno al cuerpo utópico que despierta la pasión en los jóvenes, un maniquí que bien podría aludir a Constancia, andaluza de otro relato. ${ }^{9}$ La seducción media el deseo sexual triangular, mientras que los celos modelan la relación de Toño y Bernardo con la muñeca. La teoría freudiana asegura que la atracción sexual resulta el principal mediador entre sujetos. Pero, iqué sucede cuando se ejerce de un sujeto hacia un objeto? Según Baudrillard, "la posesión-pasión del objeto es, valga la expresión, un modo moderado de la perversión sexual" (1968: 113, 114). Esta premisa permite establecer que los personajes, al legitimar y disfrutar su obscena pasión hacia el maniquí, establecen con la Desdichada un vínculo perverso.

La parafilia lleva a los jóvenes a un estado de neurosis. Freud advierte que los síntomas psiconeuróticos constituyen, en parte, "la expresión convertida de pulsiones que se designarían perversas [...] la neurosis es, por así decir, el negativo de la perversión” (1996: 150). Una vez inmersos en el cuadro neurótico, Toño y Bernardo empiezan a sufrir alteraciones anímicas. La irritabilidad se vuelve el pan de cada día como resultado del sufrimiento, pena y celos que viven en el ático. Baudrillard explica tales conflictos: "Este complejo de celos [...] rige también [...] al

9 En la novela homónima, Fuentes describe a Constancia como una mujer sensual ya entrada en años, lo que hace suponer que de joven, es decir, con la edad que aparenta el maniquí, era mucho más seductora: "La miro a ella detenida allí, a los sesenta y un años, una andaluza protegida hasta la última sombra de los rayos del sol, Constancia color de azucena, Constancia de estatura mediana y pierna corta, talle aún estrecho pero tobillo grueso, amplio busto y cuello largo: ojos dormidos, ojerosos, un lunar en la boca y el pelo entrecano restirado, desde siempre, en el chongo. No usa peinetas, aunque sí unas horquillas plateadas, nada usuales, puesto que tienen forma de llaves, con las que se sostiene el pelo" (1990: 19). simple reflejo de propiedad. Es un esquema poderoso de sadismo anal que conduce a ocultar la belleza para ser el único en disfrutarla” (1968: 112). Esta conducta, que "se difunde ampliamente en la relación de los objetos” (1968: 112), es constitutiva de la perversión sexual. Así se justifica que, en secreto y de manera sucesiva, Toño secuestre a la Desdichada en el baño para poseerla en ese espacio heterotópico, un 'otro lugar' vedado a la presencia de Bernardo, donde puede disfrutar su utopía erótica al margen del ambiente tóxico de la convivencia. El siguiente momento clave en la escalada de celos ocurre en la cena donde los jóvenes invitan a Arturo Ogarrio, Ventura del Castillo y Teófilo Sánchez. Aquí, el maniquí adquiere el reconocimiento de la comunidad de amigos, quienes la confunden y perciben como a una mujer.

Arturo Ogarrio dejó caer los brazos y dijo vámonos ya, creo que estamos invadiendo la vida privada de esta gente. Buenas noches, señora - le dijo a la Desdichada sostenida de un brazo por Bernardo, del otro por mí-. Gracias por su exquisita hospitalidad. Espero corresponderla un día de estos (79).

A partir de ese suceso, el maniquí adquiere definitivamente el estatus de mujer. Culmina su tránsito hacia la humanización o, en palabras de Girard, hacia el devenir sujeto. Por otro lado, al reafirmar su preferencia por Toño, se complejiza aún más el triángulo del deseo mimético (Esquema 3).

La cena queda marcada por los celos de Bernardo. El conflicto estalla cuando, al sentarla entre los jóvenes, la muñeca parece recargarse sobre Toño: "Bernardo se levantó temblando, la miró acurrucada así, reposando sobre mi hombro —así - y la tomó de los hombros —así, así- la agitó, yo no supe qué hacer" (79). Una vez concluida la reunión, Bernardo se marcha colérico y su amigo se queda a solas con la Desdichada. 
Toño (Objeto)

Fuente: Elaboración propia.

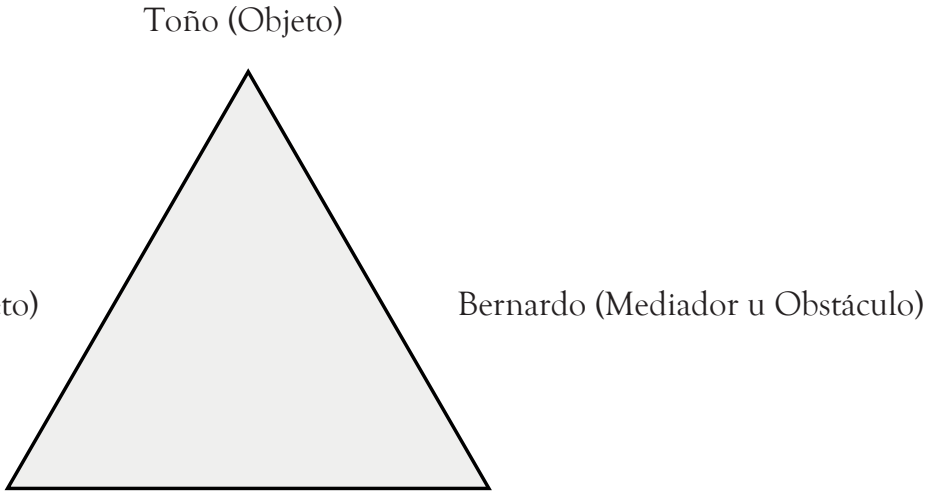

Ella comienza el asedio de la seducción: "Me dijo al oído, con un acento de polvo: [...] ¿Quieres poseerme y no eres capaz de pensar en una muerte que me haga adorarte? iPues yo te diré lo que haré contigo, Toño, re-Toño!" (81). Acaso el maniquí cobró voz o quizá Toño desarrolló los síntomas de la esquizofrenia que también padeció Nerval, lo cierto es que este hecho forma parte de una fascinación que, como señala Baudrillard, siempre se desprende del mal. Toño cede a sus pulsiones perversas y pasa la noche con la Desdichada: "La exploré con minucia, como a una amante verdadera. No dejé un centímetro de su cuerpo sin observar, sin besar" (81). La concreción del acto sexual entre Toño y la muñeca exacerba los celos de Bernardo hasta volver insostenible la convivencia. El traductor, sujeto del deseo original, explota:

Yo la vi primero, no sé qué digo, no importa, ella puede preferirme a mí, cuidadito, por qué no había de preferirme a mí, soy más guapo que tú, soy mejor escritor que tú, soy... ino me amenaces, cabrón! iNo me levantes la mano! Yo sé defenderme, no lo olvides, lo sabes muy bien, icabrón! No estoy manco, no soy de palo, no soy (82).

Finalmente, Bernardo se marcha de la casa y abandona a los amantes. El triángulo parece quebrarse, pero la Desdichada, ahora con la función de sujeto, juega sus cartas. Baudrillard afirma que "lo femenino seduce porque nunca está donde se piensa”, y allí radica su fuerza (1981: 8). Para el filósofo, la presencia de un tercero exacerba el deseo, por eso el maniquí intenta recuperar a Bernardo. De este modo puede generar nuevos celos que alimentan el anhelo de los jóvenes y asegura la continuidad de la máquina deseante. La muñeca araña a Toño para llamar la atención de su amigo, lo seduce con el juego sexual y la promesa de su cuerpo, aunque luego, nuevamente, lo desdeña:

$$
\begin{aligned}
& \text { Cuando la cargué — cuenta Bernardo_- me dijo } \\
& \text { secretamente: Vísteme. Piensa en mí, desnu- } \\
& \text { da. Piensa en toda la ropa que he ido dejando } \\
& \text { abandonada en cada casa donde viví [...] serás } \\
& \text { capaz de vestirme, mi amor, podrás cubrir mi } \\
& \text { cuerpo desnudo, astillado, roto: nueve anillos } \\
& \text { de piedra luna quiero, Bernardo (me dijo con } \\
& \text { su voz más secreta); ime los traerás?, ¿̇no me } \\
& \text { dejarás morir de frío?, ¿serás capaz de robar- } \\
& \text { te estas cosas?, rió de repente, porque no tie- } \\
& \text { nes un clavo, iverdad?, eres un pobre poeta, } \\
& \text { no tienes dónde caerte cadáver, rió mucho y yo } \\
& \text { la dejé caer (82). }
\end{aligned}
$$

El incidente enfurece a Toño, quien considera que su amigo es incapaz de darle un trato delicado a 
la Desdichada. Los personajes no usan la palabra 'celos'. Se mantienen tensos, sin hablarse por días. Bernardo decide dejar a los amantes solos la mayor parte del tiempo. En ocasiones ni siquiera regresa a dormir. Mientras tanto, la relación entre Toño y la mujer-maniquí se vuelve cada vez más íntima:

He debido cederle mi cama y el temblor de sus manos es atroz. No puede vivir y dormir de pie, como un caballo. Rápido. Le he preparado caldo de pollo y arroz blanco. Me lo agradece con su mirada antigua [...] La Desdichada duerme, duerme a mi lado (82).
Tal como había previsto el maniquí, tras marchase Bernardo el triángulo mimético comienza a cambiar. Toño extraña a su amigo, empieza a preocuparse por su ausencia, le increpa: “iCrees que ella tiene derecho a interponerse entre tú y yo, destruir nuestra amistad, hechizarte, entorpecer tu vocación, liberarte para el mal, frustrar tu romanticismo monogámico, introducirte en su perversidad hambrienta de formas?" (91). Paulatinamente, el objeto de deseo de Toño se traslada a Bernardo, y la muñeca se convierte en el mediador que obstaculiza la amistad (Esquema 4).

\section{ESQUEMA 4}

Bernardo (Objeto deseado)

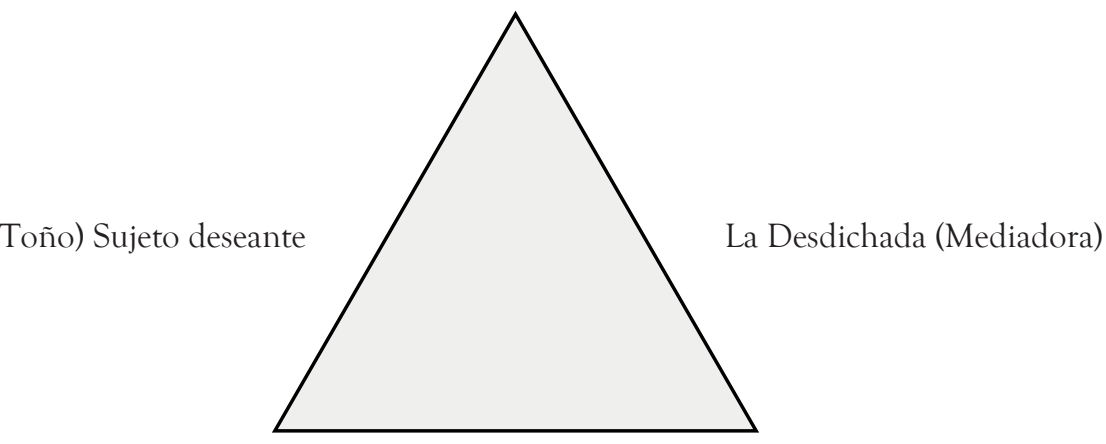

Fuente: Elaboración propia

Con la ausencia de Bernardo comienza a desmoronarse la relativa, aunque tensa estabilidad del triángulo del deseo mimético. Sin el mediador que exacerba el deseo, la pasión entre los amantes se disuelve de a poco. Además, Toño ha perdido su modelo a imitar, pues el suyo es un 'deseo copiado de otro deseo'. A medida que se fractura el triángulo, el placer se diluye, con ello ocurre la ruptura de la máquina deseante, lo cual sentencia a muerte al maniquí. Al ceder su posición como objeto de deseo, la madera pierde el sentido de objeto amado que le atribuyen los coleccionistas. Si antes se afirmó que la erotización de la muñeca acelera su tránsito hacia lo humano, ahora podemos decir que la pérdida de sensualidad la condena. La Desdichada se aboca a un proceso involutivo que, según las teorías de Deleuze, conlleva "la disolución de sus formas" (Deleuze y Guattari, 2004: 273).

Paso horas enteras en vela, atento a sus quejas, a sus necesidades [...] Sueño que hablo con ella. Pero ella habla sola. Yo hablo pero ella no me escucha. Le habla por encima de mi cabeza, o a mi lado, a otra persona que está arriba o detrás de mí; yo no la veo. Esto me 
hace sentirme enfermo de melancolía. Creo en alguien que no existe (87).

La Desdichada se vuelve peligrosa, a ratos tierna, a ratos agresiva: "[N]ace a ciertas horas, parece moribunda en otros cuadrantes; está enamorada de la metamorfosis, no de la forma inalterable de una estatua o de un poema" (91). La violencia se apodera y rige el comportamiento de los personajes. La intensidad del deseo sexual se traslada hacia el deseo de matar. El cuerpo del maniquí también se deteriora. La disolución de la utopía y la pérdida del atractivo sexual aceleran su fenecimiento. La Desdichada comienza un periodo de regresión, se orina en la cama, le abandonan las fuerzas. Toño pierde el control de la situación y le ruega a Bernardo que regrese, pero él se niega.

La muerte se instala como parte del vínculo entre los personajes. Por momentos se vislumbra como la única salida posible al conflicto. Colérica, la Desdichada increpa a su amante: "iCómo prefieres morir? ¿Te imaginas crucificado? ¿Te imaginas coronado de espinas? [...] i No te tapes los oídos, pobre diablo! ¿Tú me quieres poseer y no eres capaz de pensar en una muerte que me haga adorarte?" (93). Toño reacciona y precipita el desenlace del conflicto. Justo en el baño, el lugar heterotópico donde se consumó la seducción, el joven comete el crimen:

Oí el claro glú-glú del agua embelesada. Entré despacio al baño, apartando la cortina de cuentas y su rumor asiático. Allí estaba ella, en el fondo de la tina colmada de agua hirviente, despintada ya, apenas con una insinuación de ceja, de labio, de mirada lánguida, astillándose ya, llena de las ampollas del calor mojado, sumergida en un cristal de muerte, su aparador final, la larga cabellera negra al fin liberada, flotando como algas, limpia al fin, ya no apelmazada, dormida mi mujer en la vitrina de agua donde ya nadie puede verla o admirarla o desearla: imaginarla ya nunca más, desdichada (93).
La muerte de la muñeca posibilita la satisfacción de la última versión del triángulo del deseo mimético (Esquema 4). Una vez suprimido el obstáculo-mediador, Toño alcanza el verdadero objeto de su deseo: recuperar el vínculo con Bernardo. También libera a su amigo (obsesionado con la traducción del poema de Nerval) de sus ataduras literarias, pues aniquila la imitación que éste vislumbró de su modelo. A pesar de la paulatina recuperación del equilibrio, los jóvenes imitan al viudo del soneto hasta el final de la obra, cuando colocan a la Desdichada en un ataúd. Bernardo y Toño encierran al maniquí en el féretro y sellan la caja funeraria, de este modo culmina la triada del deseo y el amor ilusorio. Baudrillard prevé este momento de ruptura definitiva: "[con frecuencia] el sujeto termina por destruir el objeto o el ser oculto, por un sentimiento de imposibilidad de conjurar totalmente la adversidad del mundo y su propia sexualidad. Allí está el fin lógico e ilógico de la pasión" (1968: 113).

Tras este acontecimiento, la 'personalidad' de la Desdichada se fuga del maniquí, ese cuerpo utópico que Toño 'asesinó' en la bañera, para habitar otro objeto que el narrador revela un cuarto de siglo después, cuando se reencuentran los amigos. Aquella noche, después de las correrías por la ciudad, terminan ebrios a la entrada de la Catedral. Justifican su comportamiento por la jovialidad que les produce la reunión, el baile, y la compañía de Ámbar y Estrella, dos presuntas amantes. Están mareados y se sostienen de una reja. Bernardo busca la mirada de Toño, pero él tiene la vista fija en el oscuro altar. Ambos contemplan la imagen de la Virgen de la Macarena:

La Virgen [...] lloraba mirando a su hijo muerto tendido sobre el regazo materno [...] Por sus mejillas corren lágrimas gordas, negras, hondas $[. .$.$] Su escultor le dio un rostro de fac-$ ciones clásicas, nariz recta y ojos separados, lánguidos, entreabiertos, y una boca tiesa, chiquitita y pintada en forma de alamar [...] También tiene un cuello largo, ideal para su 
gorguera [...] En la mano izquierda, le falta el dedo anular. Sus párpados alargados, como de saurio, nos miran entrecerrados, nos miran a Toño y a mí como si fuésemos muñecos inanimados. Son ojos tristes, de una gran desdicha. Como si un gran mal le hubiese ocurrido en otro tiempo (100-101).

Con esta escena final se completa el tránsito de la Desdichada por distintos cuerpos: la 'personalidad' que antes fue de Constancia, de la Santa difunta del poema "El desdichado", del maniquí con traje de novia, ahora ocupa un sitio en el altar de la iglesia, como virgen. Más aún, conserva —o los escritores así lo creen- las huellas de otro tiempo, cuando fue virginal y perversa entre sus manos. Una vez más, la fantasía de los amigos se corona con las imágenes que hace veinticinco años dominaron su mente y sus deseos: la metáfora que adoptaron para alcanzar la epifanía los vuelve a seducir.

\section{Conclusiones}

La Desdichada, considerada en un primer momento un objeto, no-persona o no-humana, pasa por un proceso de personificación en la nouvelle de Carlos Fuentes. Esto sucede por varios caminos. El primero de ellos se evidencia mediante la intertextualidad con la protagonista de la obra Constancia. Gracias a esta coincidencia se deduce que la Desdichada constituye el cuerpo utópico soñado por el personaje. En una escena onírica, Constancia ve que dos estudiantes se roban un maniquí de un aparador y lo llevan a vivir a su estudio. Luego, se enamoran de la muñeca, se disputan su amor y terminan destruyéndola. Al final, el maniquí reaparece con la forma de una virgen y los mira como si ellos fueran los muñecos de palo. La trama del sueño de Constancia se concreta y desarrolla en la segunda novela para vírgenes de Fuentes. En esta conexión intertextual se constata el primer rasgo de personificación del maniquí, que radica en su corporeidad utópica. Además, se verifica la función de los objetos, en este caso la que ejerce la Desdichada como vaso de lo imaginario. En otras palabras, del cuerpo utópico de Constancia en el maniquí se desprende lo humano de la muñeca.

El segundo camino para la personificación del objeto se comprueba en las marcas corporales que ostenta la Desdichada. En la narración, el vestuario constituye uno de los rasgos de su identidad. El distinguido vestido de novia y el velo que cubren el cuerpo de la muñeca despiertan el deseo de los jóvenes. Este primer afeite determina la personalidad del maniquí. Más adelante será sustituido por la vestimenta de un pederasta y de prostitutas. De esta manera comienza un proceso de sexualización que acelera el tránsito hacia la humanización. El otorgamiento de un nombre propio y el cariño que le profesan Toño y Bernardo se vuelven cruciales. Una vez que la Desdichada adquiere un cuerpo utópico y se le proyecta como humana desde la fascinación, el deseo sexual de los estudiantes, que antes se dio de sujeto a objeto, pasa a darse de sujeto a sujeto.

En este artículo se pone de manifiesto el poder de la mímesis como vehículo para obtener placer. El análisis de la obra demuestra que la imitación despierta una fuerte rivalidad entre el sujeto deseante y su mediador, quien no sólo impulsa el nacimiento del deseo, sino que promueve su concreción. Al traducir el poema de Nerval, Bernardo reproduce lo que escribe el poeta y traslada sus sensaciones a su experiencia personal con la Desdichada. Toño y Bernardo protagonizan un triángulo de deseo en donde el modelo a imitar apunta a las imágenes del poema citado, lo que valida la teoría de Girard de que en los personajes se impone un modelo de imitación con base en sus lecturas. Finalmente, se enfatiza el funcionamiento de la máquina deseante, el cual varía de acuerdo con el juego de tensiones, pasiones y celos que provoca el cuerpo utópico de la Desdichada, personaje de ficción que, sin embargo, despierta un deseo tangible y real. 


\section{REFERENCIAS}

Aristóteles, Poética (s/f), Escuela de Filosofía, Universidad ARCIS, disponible en: www.philosophia.cl/biblioteca/aristoteles/poetica.pdf

Baudrillard, Jean (1968), El sistema de los objetos, París, Éditions Gallimard.

Baudrillard, Jean (1981), De la seducción, Madrid, Cátedra.

Deleuze Gilles y Félix Guattari (2004), Mil mesetas: Capitalismo y esquizofrenia, Valencia, Pre-Textos.

Foucault, Michel (2010), El cuerpo utópico. Las heterotopías, Buenos Aires, Ediciones Nueva Visión.

Freud, Sigmund (1996), Tres ensayos sobre teoría sexual, en Obras Completas, vol. VII, Buenos Aires, Amorrortu Editores.

Fuentes, Carlos (1990), Constancia y La Desdichada, en Constancia y otras novelas para vírgenes, disponible en: https:// www.megaepub.org/libro/constancia-y-otras-novelas-para-virgenes/

García, Pilar (2018), "Literatura, historia: crisis de las disciplinas y contextos para la ficción", Revista de Literatura, enerojunio, vol. LXXX, núm. 159, págs. 35-65, disponible en: http://revistadeliteratura.revistas.csic.es/index.php/revistadeliteratura/article/view/439/452

Genette, Gérard (1989), Palimpsestos. La literatura en segundo grado, Madrid, Taurus.

Girard, René (1963), Mentira romántica y verdad novelesca, Caracas, Universidad Central de Venezuela.

Hernández, Raúl (1991), "La constancia y otros prodigios de Carlos Fuentes”, La PH, núm. 79, julio-septiembre, pp.228-236.

Herrera, Bernal (1991/1992), "Aspectos del deseo en la obra de Carlos Fuentes”, INTI, Revista de Literatura Hispánica, núm. 34/35, pp. 107-118.

Mesa Gancedo, Daniel (2002), Extraños semejantes. El personaje artificial y el artefacto narrativo en la literatura hispanoamericana, Zaragoza, Prensas Universitarias de Zaragoza.

Nerval, Gérard de (1995), "El desdichado", disponible en: https://ciudadseva.com/texto/el-desdichado/

Lis García Arango. Licenciada en Periodismo por la Universidad de La Habana, Cuba. Doctorante en el programa de Literatura Latinoamericana de la Universidad de Concepción, Chile. 